INTERNATIONAL JOURNAL OF MULTIDisciplinARY RESEARCH AND ANALYSis

ISSN(print): 2643-9840, ISSN(online): 2643-9875

Volume 04 Issue 07 July 2021

DOI: 10.47191/ijmra/v4-i7-17, Impact Factor: 6.072

Page No.- 999-1005

\title{
The Demographic Implications of Crop Farmers-Pastoralists Conflict in Benue North-West, Nigeria
}

\author{
Godwin Kwanga ${ }^{1}$, Joseph Enefu ${ }^{2}$, James Ikyernum ${ }^{3}$, Patricia, I. Ali ${ }^{4}$, Onyeche Anita Makyur ${ }^{5}$ \\ 1,2,3,4 Department of Geography, Benue State University, Makurdi, Nigeria \\ ${ }^{5}$ Department of Hospitality and Tourism Management, Federal University, Wukari-Taraba State
}

\begin{abstract}
Conflicts between crop farmers and pastoralists have become a common feature of economic livelihood in West Africa. The study assessed the demographic implications of crop farmers-pastoralists conflict in Benue North-West, Nigeria. The study adopted a cross-sectional survey design and a sample of 120 respondents was purposively selected from the three LGAs mostly affected by the pastoralists' attacks. Data were collected using structured questionnaires, key informant interview and field observations and analyzed using descriptive statistics (frequency, percentages and mean). The study in its course found that availability of evergreen arable land $(3,27)$, competition over available evergreen arable lands (3.0), damage to crops (3.12) and the proliferation and availability of cheap small arms and light weapons (2.52) are the major causes of conflict in the area. The study also revealed that the conflict has both short and long term demographic implication on the affected communities. The study recommended sustainable measures towards addressing conflict in the affected communities.
\end{abstract}

KEYWORDS: Demographic implication, Pastoralists, Crop Farmers, Conflict

\subsection{INTRODUCTION}

One of the most serious security challenges facing Benue State in contemporary times is the recurrent conflicts between crop farmers and the pastoralists. Violent conflicts between crop farmers and pastoralists have, for a long time, been a common feature of economic livelihood in many parts of West Africa with consequences on human and animal lives, properties, peaceful coexistence, and orderliness (Olaniyan, 2015). Although the crop farmers-pastoralists conflict is not exclusive to Benue State, it has taken dangerous dimensions in the Benue valley and most parts of the North-central geo-political zone. The introduction of small arms and light weapons, and other dangerous arsenals to the conflict theatre from 2011 till date has exacerbated the crises (Abbas, 2019).The concept of conflicts in general and specifically the crop farmers-pastoralists conflict is not a new phenomenon to the conflict map of Africa. However, it has recently become a significant threat to food security and development in Nigeria, especially in Benue State; therefore this calls for more decisive lines of action to stem the tide.

The re-emergence of democratic rule in 1999 herald renewed conflicts and convulsions ranging from ethnic crises, religious intolerance, political instability, the proliferation of small arms and light weapons, insurgencies, terrorism, sectarian violence, absence of good governance as well as lack of development among others. Nation building continues to suffer from strong divisive forces of ethnicity, religion, sectarian violence, politics and natural resource conflicts, which presupposes the weakening of national cohesion and integration (Mustapha, Abdullahi and Bilkisu, 2019). In this context therefore, we can situate the contestation for land based resources between the crop farmers and pastoralists conflicts of interest (Genyi, 2014). According to Genyi (2014), historically the two groups have related peacefully for generations, with little bouts of clashes here and there but at low levels, and using traditional avenues of conflict resolution, peace was often achieved. The emergence of widespread hostilities between the two groups began in the 1990s in Taraba State over grazing spaces (Tonah, 2016). Since mid2000, North-central Nigeria became a theatre of armed contestation when attacks by suspected Fulani herdsmen on crop farmers, their homes, schools, markets and crops became a constant feature of the inter-group relations within the study area and other parts of the country.

Some of the most prominent conflicts in Nigeria are the resource based conflicts. Several instances abound, such as: the upsurge in hostilities and militancy in the oil rich Niger Delta Region in Southern Nigeria, and the widespread violence between the two dominant production communities (crop farmers and pastoralists) in the Northern parts of the country. Farmer-herder 


\section{The Demographic Implications of Crop Farmers-Pastoralists Conflict in Benue North-West, Nigeria}

conflicts have existed since early beginning of agriculture in Africa (Mustapha, Abdullahi and Bilkisu, 2019). Nevertheless, its continued manifestation as violence against the backdrop of resource scarcity, increase in the population of resource users, inadequate grazing reserves and poor state of the existing ones, non-adoption of the modern animal husbandry and ranching systems, unequal resource distribution and the consequent failure of patrimonial states has negated development efforts. The North-central geopolitical region of Nigeria has been susceptible to the antecedents of what Kaplan (1994) described as the "Coming Anarchy". Farmer-herder conflicts are among the key manifestations of this anarchy and this is linked with the region's socio-economic and political ecology (Ukamaka, Danjuma, Mbolle, and Mbadiwe, 2017). The farmer-herder conflict took dangerous dimensions in Benue state especially from 2011 when sophisticated small arms and light weapons were introduced to the conflict arena, especially in the area of this study; Gwer west, Guma and Makurdi local government areas.

Benue State has 23 local government areas; 12 of these are seriously affected leading to serious threat to food security; unemployment, closure of schools and businesses, cattle rustling, kidnapping, robberies and criminality in general and the wanton destruction of lives and property, generating thousands of internally displaced person (IDPs). The worst hit LGAs cut across all the three zones in the state which includes; Makurdi, Gwer West, Guma, Agatu, Ogbadibo, Kwande, Logo, Ukum and Katsina-Ala among others.

The increasing southward drift by the pastoralists who are predominantly Fulani, and their increasing concentration around the middle belt region, coupled with the increasing population of the farmers in the region who are largely crop farmers has continued to reduce available land for crop farming and the grazing of cattle. Olaleye (2010) was of the view that the movement of pastoralist from one area of the country to another is usually caused by the increasing demand for fresh grazing grounds especially during draught periods when the pastoralists move southwards because of the availability of pasture and water. In most cases, the pastoralists encounter problems with the local people because farmers' crops are being destroyed by their cattle, the soil gets compacted and streams get polluted by the cattle. Unfortunately, these conflicts not only continue to persist, they are on the rise and fast becoming a nationwide phenomenon.

According to Ekong (2013), 64 percent of Nigerians live in the rural areas and their primary occupation is farming. Equally, most farming households operate land owned through inheritance and acquisition through family ties, therefore, more than 50 percent of the crop farmers own their lands, of which same cannot be said of the pastoralists who are settlers in transit (Okinmadewa, 2002). Besides, the land tenure system in the region which is mostly through family inheritance does not favour the pastoralist for free grazing. Arable crop farmers and cattle producers have not only intensified the use of land, they have also been exploring other frontiers for farming and grazing including the Fadama areas. Since the 1980's, there has been a marked expansion of cultivation of the fadama (riverine and valley-bottom) areas (Blench, 2017). This means that both the crop farmers and the pastoralists will engage in fierce struggles for access to such valuable lands which more often than not, results in increased conflicts and violence.

Farmlands that are usually allowed to lie fallow for natural rejuvenation of the soil are fast disappearing, while lands that traditionally provide dry season grazing for pastoralists are becoming shorter in supply (Mustapha, Abdullahi and Bilkisu, 2019). This has heightened the frequency and intensity of competition among the various land users. It has also engendered this competition driven conflict between the arable crop farmers and cattle herdsmen which have become common occurrence in many parts of Nigeria (Genyi, 2014).

According to Ibeh (2014), the pastoralists before 1980 had cordial and mutual relationships with the crop farmers in Benue North-west, especially in these three local government areas: Makurdi, Gwer west and Guma. However, on seeing the quantum nature of green land spread across the Benue trough, Ibeh (2014) reported that the Fulani pastoralists began to seek means to capture the land from the crop farmers. Furthermore, there is an increasing concentration of pastoralists coming from the Northern parts of the country to take advantage of the all year green grass and abundant water spots in Benue state. For instance, Federal livestock Department Report (2004) indicated that the influx of cattle Fulani from Nassarawa to Benue is on the increase at a rate of $3-4 \%$ annually; and $1.5-2 \%$ leave the valley every year, while $0.5-0.8 \%$ of the cattle is consumed as meat in abattoirs and the slaughter houses. The implication of this situation is always a large percentage of livestock left in the Benue valley every year. As was reported, the type of grass, the soil type that encourages and supports green vegetation cover creates an enabling environment suitable for the herdsmen to desire to pasture in this valley. Hence, the immediate cause of the conflict is over the 'material' needed for 'existence' because each is struggling to survive or exist, and each group depends on the same material called the 'green of the land'(Tonah, 2016).

Judging from the foregoing, the conflict between the crop farmers and the pastoralists will continue to erupt with devastating social, economic and political effects on the affected communities if holistic steps are not taken to address the issue from its root cause. This is also taking into account the reports of researchers such as Dzurgba (2006), Lyam (2006) and Musa, 


\section{The Demographic Implications of Crop Farmers-Pastoralists Conflict in Benue North-West, Nigeria}

Shabu and Igbawua (2014) and the investigative panels and committees such as Tyoshin Traditional Council and Isherev Progressive Association in the study area who have outlined remote and immediate causes of the problem in the affected areas. The methods to be adopted by the government and all stakeholders ought to be all encompassing and multi-dimensional because of the far reaching security implications of the conflict on the development of the affected communities, and food security in Nigeria. Therefore the need for the modernization of both methods of production (crop farming-pastoralism) is a panacea, requiring government to take the bold steps of creating the enabling environment for both production systems to thrive in a symbiotic relationship devoid of mutual suspicion and animosity.

Every farming system has a boundary which separates it from the larger system that makes up the environment. Conflicts and violent clashes between farmers and nomadic cattle herders have been a common feature of economic livelihood in West Africa (Tonah, 2016). The boundary represents the limits in the larger system. Farmers regularly compete with nomadic herders for farmland, pastures, water, trees and the use of rangeland in general (Akpaki, 2002). There have been violent clashes between nomadic herdsmen and farmers in several parts of Nigeria for several years. The clashes are occasioned by the destruction of agricultural farms of the farmers by the cattle of the nomadic herdsmen.

However, in spite of the spate of violent clashes between nomadic herdsmen and farmers in Nigeria, adequate social research attention has not been given to the demographic implications of these clashes considering the tremendous population increase. It is against this background that this study attempts to examine the demographic implications of nomadic herdsmen and farmers clashes in Nigeria.

\subsection{MATERIALS AND METHODS}

\subsection{Study Area}

Benue north-west consist of seven Local Government Areas; however, Makurdi, Guma, and Gwer West Local Government Areas were purposively selected because they are the LGA's that have mostly suffered the frequent attacks by pastoralists. The area lies between latitude $6^{\circ} 29^{1} \mathrm{~N}-8^{\circ} 15^{1} \mathrm{~N}$ and longitude $7^{\circ} 2^{1} \mathrm{E}-9^{\circ} 40^{1} \mathrm{E}$. The area borders with Nasarawa state in the North, South by Gwer East and Tarka LGAs, West by Apa and Agatu LGAs, and East by Logo LGA and Taraba State as can be seen in Figure 1.

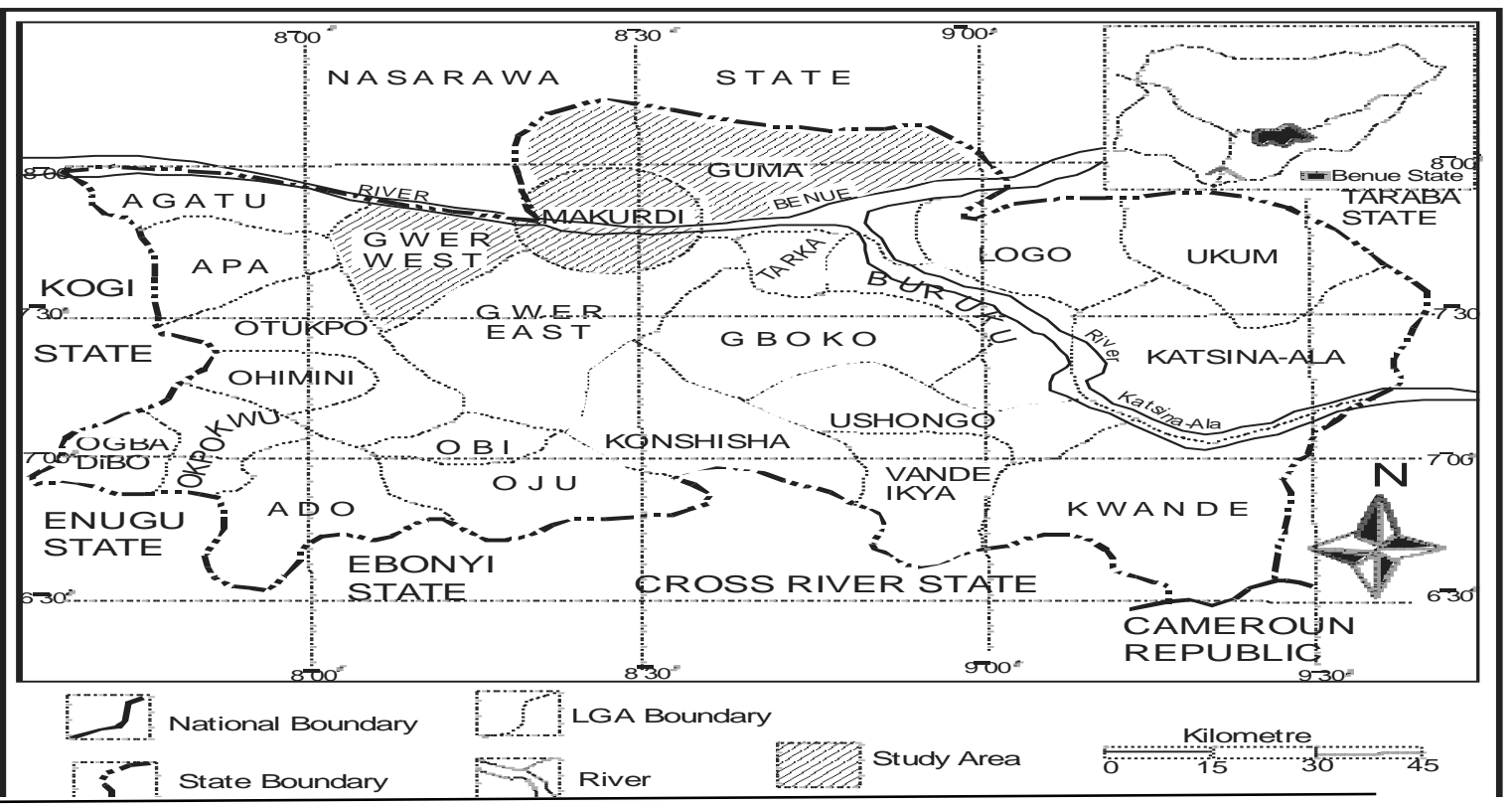

Figure 1: Benue State Showing the Study Area

Source: Benue State Ministry of Lands and Survey, 2019

The river plains and the fadama areas on the banks of the prominent river Benue and other rivers and streams in the trough have green pastures all year round which constitute the major attraction to pastoralists who traverse the entire Northcentral geo-political region. The main occupation in the area is agriculture which includes cultivation of crops and livestock farming. However, the Fulani herdsmen who are settlers in the study area are predominately pastoralists. Some crop famers also indulge in livestock rearing which includes pigs, goats, sheep, poultry and cattle but on a limited size. 


\section{The Demographic Implications of Crop Farmers-Pastoralists Conflict in Benue North-West, Nigeria}

Makurdi LGA which is one of the local governments in the area is also the state capital and has a total population of about 300,377 (NPC, 2006), with 11 council wards. Besides, Naka LGA has 15 council wards with an estimated total population of about 122,145 (NPC, 2006) while Gwer west LGA has 10 council wards with a total population of about 191,599 (NPC, 2006).

\subsection{Methodology}

This study employed a cross-sectional survey design and data were collected from a sample selected to represent a large population. Stratified sampling technique was employed considering the three crop farmers-pastoralist conflict prone local government areas in Benue state which include: Makurdi, Guma and Gwer West. Purposive sampling technique was then used to select a total of 120 respondents from the study area with forty (40) respondents selected from each of the considered LGA used for this study. Data collected from respondents using structured questionnaires was coded and summarized using Statistical Package for Social Sciences (SPSS) Version 20 software. Descriptive statistics such as frequencies, percentages and mean were used to analyze the data collected for this study.

\subsection{RESULTS AND DISCUSSION}

\subsection{Causes of Crop Farmers-Pastoralist Conflicts}

The study investigated the causes of crop farmers-pastoralists conflict in the study area. Table 1 reveals the key factors responsible for the incessant outbreak of the conflict in the area. This mean score (3.0) implies that the availability of evergreen arable land for grazing in the affected communities act as a pull factor that enticed the pastoralists to the areas resulting into the conflict. This is similar to the findings of Okoli and Altehe (2014) in their study which stated that herders tend to move from Northern and Southern Nigeria to the Middle Belt region where there is availability of vast arable land especially during dry seasons, thereby increasing the competition over farmlands consequently resulting to crisis. This implies that the more the herdsmen converge on the communities and the farmlands, the lesser the available land for crop farming becomes, and this increases potentials for conflict between the crop farmers and pastoralists. This conforms to Ayih (2013) assertion that, as the population of both the herders and crop farmer's increases; the grazing areas that were hitherto abundant are being taken over by scattered small farms, making grazing difficult.

According to the majority of the respondents (Mean=3.27), competition over arable and water point is the cause of crop farmers/pastoralist conflicts in Benue North-Wesr of Nigeria. The result also indicated that majority of the respondents attributed the crop farmers-pastoralists conflict to crop damage and compaction of farmlands by cattle hooves (mean=3.12). A study on resource use conflict between Farmers and Fulani herdsmen in Guma Local Government Area of Benue State, Nigeria by Musa, Shabu and Igbawua (2014) also came out with the similar results that the destruction of crops/farmlands by cattle is one of the major causes of crop farmers-pastoralists conflict in the area. This destruction of crops and farmlands results from the competition over arable lands by pastoralists and crop farmers.

Also majority of the respondents (2.52) see proliferation and availability of cheaper small arms and light weapons as a fuelling factor of the conflicts as agreed by most of the respondents in the study area. Similar finding was also highlighted by Abbass (2019) in his study of conflict for survival between pastoralists and farmers in Northern Nigeria. In addition, pastoralist migration as a result of ecological and climate condition (mean=2.53) also fuel crop farmers/pastoralist conflicts in the study area. The information obtained from the focused group discussion also revealed that the incessant conflict between the crop farmers and pastoralists in the affected communities is prompted by the easy and illegal acquisition of fire arms by youths. They disclosed that the herders during the attacks carry different firearms including AK47, double barrels guns among others unidentified weapons. Most of the respondents opined that if both parties have no access to firearms, the level of destruction of lives and properties and the frequency of the conflicts might have been on a lighter scale.

Table 1: Respondent's Perceived Causes of Crop Farmers-Pastoralists Conflict

\begin{tabular}{|c|c|c|c|c|c|c|c|c|}
\hline \multirow[b]{2}{*}{ Causes } & \multicolumn{3}{|c|}{ Rating scale } & & \multirow[b]{2}{*}{ Total } & \multirow[b]{2}{*}{ TWV } & \multirow[b]{2}{*}{ Mean } & \multirow[b]{2}{*}{ Decision } \\
\hline & 4 & 2 & 1 & & & & & \\
\hline Availability of evergreen arable & 41 & 56 & 5 & 18 & 120 & 360 & 3.0 & Agree \\
\hline land & $34.2 \%$ & $46.7 \%$ & $4.2 \%$ & $15 \%$ & & & & \\
\hline Competition over arable land and & 68 & 28 & 12 & 12 & 120 & 392 & 3.27 & Agree \\
\hline water point & $56.7 \%$ & $23.3 \%$ & $10 \%$ & $10 \%$ & & & & \\
\hline
\end{tabular}


The Demographic Implications of Crop Farmers-Pastoralists Conflict in Benue North-West, Nigeria

\begin{tabular}{|c|c|c|c|c|c|c|c|c|}
\hline \multirow[t]{3}{*}{ Damage to crops } & 62 & 19 & 30 & 9 & 120 & 374 & 3.12 & Agree \\
\hline & $51.7 \%$ & $15.8 \%$ & $25 \%$ & $7.5 \%$ & & & & \\
\hline & & & & & 118 & & & \\
\hline \multirow{3}{*}{$\begin{array}{l}\text { Pastoral migration as a result of } \\
\text { ecological/climatic conditions }\end{array}$} & 34 & 19 & 41 & 24 & & 299 & 2.53 & Agree \\
\hline & $28.8 \%$ & $16.1 \%$ & $34.7 \%$ & $20.3 \%$ & & & & \\
\hline & & & & & 60 & & & \\
\hline $\begin{array}{l}\text { Proliferation and availability of } \\
\text { cheaper arms and light weapons }\end{array}$ & 6 & 30 & 13 & 11 & & 151 & 2.52 & Agree \\
\hline Minimum Mean Score $=2.5$ & $10 \%$ & $50 \%$ & $21.6 \%$ & $18.3 \%$ & & & & \\
\hline
\end{tabular}

Source: Authors' Survey, 2019

\subsection{Demographic Implications of Crop Farmers/Pastoralist Conflicts}

The result on the demographic Implications of Crop Farmers-Pastoralist Conflict in the area revealed that the conflict situation under review has resulted in dire humanitarian, socio-economic and political consequences. The effects of the conflict are discussed based on the empirical insight drawn from the field using relevant tools as well as exploration of relevant secondary sources.

The results clear the doubt that many people especially the crop farmers have fled from their homes and communities for their safety as a result of the security threat of the areas. The study gathered that many people from the affected communities are currently taking refuge in the IDP camps as can be seen in Figure 2 and 3 . The displacement of crop farmers from their original homes, denial of access to their farms due to insecurity have social and economic implications on both the victims and the entire society because food production is vital to the livelihood of every one. Besides, the farming population of many communities in the study area has been depleted leading to wide spread hunger and poverty among the farmers.

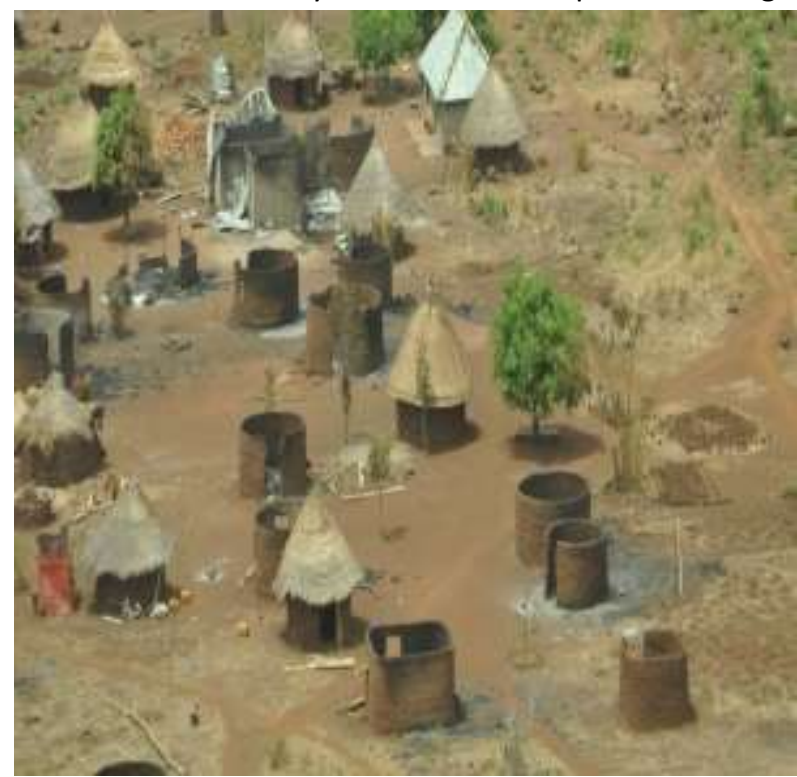

Fig 2: Tse Kumbur-Tongov ward vacated

Source: Field survey, 2018

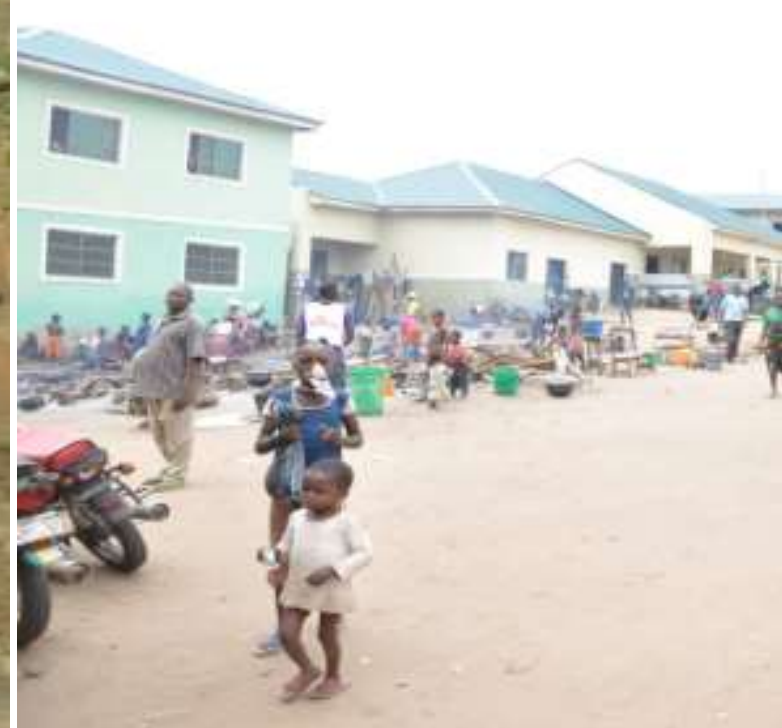

Fig 3: Refugees at IDP Camp, Abagena

Source: Field survey, 2018

The study also examined the death toll and injuries sustained by the population in the affected communities. The data presented in Table 2 shows the number of casualties recorded from different attacks by pastoralists in different communities within the study area obtained from secondary data sources from 2011-2018. The attacks on different communities of the study area as a result of the crop farmers-pastoralists has claimed 190 lives and injured many leading many people to widowhood and orphans. The number of death reported between June 2011- May 2018 was 190 persons while those injured were 52 persons (Ayua, 2018). Tyohemba (2014) reiterated that the loss of a household member through death may be a critical economic loss particularly, if that person was a major contributor to the household's livelihood. Availability and cost of labour is affected because many rural households depend on cheap family labour. 
The Demographic Implications of Crop Farmers-Pastoralists Conflict in Benue North-West, Nigeria

Table 2: Casualties of Farmers-Pastoralists Conflicts in the Area between 2011-2019

\begin{tabular}{llll}
\hline Date of attacks & Communities attacked & No. of deaths & No. injured \\
\hline $20^{\text {th }}$ June, 2011 & Anchicha village, Gwer East LGA & 4 & 2 \\
$8^{\text {th }}-10^{\text {th }}$ Feb.,2011 & Tyoughatee district, Gwer west LGA & 17 & - \\
$1^{\text {st }}$ April, 2011 & Mbayer district (Yogbo), Guma LGA & 10 & 5 \\
$13^{\text {th }}$ April, 2011 & Mbakera community, Gwer West LGA & 2 & 3 \\
$24^{\text {th }}$ May, 2011 & Yelwata community, Guma LGA & Nyiev district (Udei) Guma LGA & - \\
$20^{\text {th }}$ June, 2011 & Nyijir Mbagwen Makurdi LGA & 20 & - \\
$12^{\text {th }}$ Nov. 2011 & Sengev Ward Gwer-West LGA & 2 & - \\
$4^{\text {th }}-5^{\text {th }}$ March, 2012 & Ukusu district Gwer West LGA & 33 & - \\
$18^{\text {th }}$ Feb. 2014 & Nyamshi comm. Gwer West LGA & 5 & 3 \\
$23^{\text {rd }}$ Feb. 2014 & Sengev/Tongov districts Gwer West & 3 & 3 \\
$26^{\text {th }}$ March, 2014 & Adaka community, Makurdi LGA & 6 & 5 \\
$21^{\text {st }}$ Feb, 2014 & Ichei Adem, village Makurdi LGA & 3 & 4 \\
$19^{\text {th } ~ J a n ., ~} 2014$ & Nyiev/Mbadwem wards Guma LGA & 7 & 23 \\
$1^{\text {st }}$ Jan., 2018 & Mbalom district, Gwer West LGA & 49 & 4 \\
$24^{\text {th }}$ April, 2018 & Kura Village, Makurdi LGA & 17 & - \\
$23^{\text {rd } \text { May, } 2018}$ & 3 & \\
\hline
\end{tabular}

Source: Adopted from the Report compiled by Ter-Tyoshin HRH Ayua Abomtse, 2018

\subsection{CONCLUSION AND RECOMMENDATIONS}

Conflict in agrarian communities largely revolves on livelihood issues or resource based. The results show that in addition to some structural factors, conflicts are associated with livelihood pressure and competition between crop farmers and pastoralists. Specifically, the dominant composite causes revealed in the study are competition over evergreen arable land and water point, damage to crops and compaction of farmland by cattle, pollution and proliferation and availability of cheaper arms and light weapons.

Consequently, the crop farmers-pastoralist conflict developed demographic implications reflected on the social, economic and political lives of crop farmer's population in the area with many killed while others rendered homeless, taking refuge in different DP camps across the state. The livelihood structure including life ad properties, food security and wellbeing of crop farmers and pastoralists are affected or threatened and compromised which contribute to deaths, poverty, food and nutrition, insecurity and poor health of crop farming communities and further escalation of conflicts. Therefore, sustainably addressing conflict in the communities is critical to achieving economic, agricultural development and sustainable livelihood of the population in the affected communities.

\section{REFERENCES}

1) Abbas, I.M. (2019). "No Retreat, no surrender: Conflict for survival between Fulani Pastoralists and farmers in Northern Nigeria". European Journal Science, 8(1):331-346.

2) Akpaki, A. Z (2002). Conflict management and Resolution. Benin; Dietric publishers

3) Ayih, S.O (2013).Nasarawa State: Past and present. Abuja, Nigeria. Umbrella Books.

4) Azuonwu, G. (2002). Understanding group dynamics: Effective tool for conflict resolution in Nigeria. Ibadan: EviColeman Publication.

5) Blench, R. (2017).The transformation of conflict between pastoralists and cultivators in Nigeria. Paper in press for a special issue of the Journal Africa.ed.M.Montz. Retrieved From http://www.rogerblench.infor/Development/Nigeria Livestock survey.pdf on December 19, 2017.

6) Dzurgba, A. (2006). Prevention and Management of Conflict in Honour of Prof.Segun Odunuga. Ibadan: Loud Books Publishers.

7) Genyi, U. (2002). Land use patterns and conflicts between the pastoralists and crop farmers. Case of Mezam division, North-West Region, Cameroon. Monograph University of Dschang-Cameroon. pp. 15-25.

8) Ibeh, B. I. (2014). Causes, effects and resolution of farmers-nomadic cattle herders conflict in Delta State, Nigeria. International Journal of Sociology and Anthropology.. 1(2): 47-54. 


\section{The Demographic Implications of Crop Farmers-Pastoralists Conflict in Benue North-West, Nigeria}

9) Kaplan, J. C. (1974). The Sahelian Drought and its Demographic Implications. (OCL papers, No. 8), Overseas Liaison Committee, American Council on Education, Washingston D. C.

10) Lyam, A.A. (2006). Kwande Crisis:A Community Conflict of many Interests. Makurdi: Selfers Books.

11) Musa, S. D. Shabu T. Igbawua M. I. (2014). Resource use conflict between farmers and Fulani herdsmen in Guma Local Government Area of Benue State, Nigeria International Journal of basic and applied research.

12) Mustapha, A.L, Abdujjahi, A And Bilkisu, L.G (2019). Effects of insurgency on socio economic and political development of Yobe State, Njgeria. Kashere Journal of Management Sciences 2(1) 1-10

13) Okoli, A.C, Atelh, G.A. (2014). Nomads against natives: A Political ecology of herder/farmer conflicts in Nasarawa State, Nigeria. Am.Int. J. Contemp. Res. 4(2):76-88.

14) Olaniyan, A.U. (2015). Causes, effect and resolution of farmers. Nomadic cattle herders conflict in Delta state, Nigeria. International Journal Sociology and Anthropology 1(2):47-54

15) Olaleye, R.S. (2010). Perceived effectiveness of conflict resolution methods for improved Farmer-Pastoralist relationship in Chikun Local Government Area of Kaduna State- Nigeria. The Nigerian Journal of Rural Extension and Development, 3:54-58.

16) Okinmadewa, D. (2002). Cultural violence. Journal of Peace Research 3 (3)

17) Tonah, S. (2016). Farmer -Herder Conflict in Volta region of Ghana. Journal social sci. 2:6-10

18) Tyohemba, K. (2014). “Food Scarcity Looms over Herdsmen, Farmers Clashes”, New Telegraph, Friday, May 30, P. 34. www.Texas Food.

19) Ukamaka, D.M., Danjuma, S. E., Mbolle, J. E and Mbadiwe I. E. (2017). Livelihood issues in herdsmen-farmers' conflict among farming communities in Kogi State, Nigeria. African Journal of Agricultural Research, 12(24) 